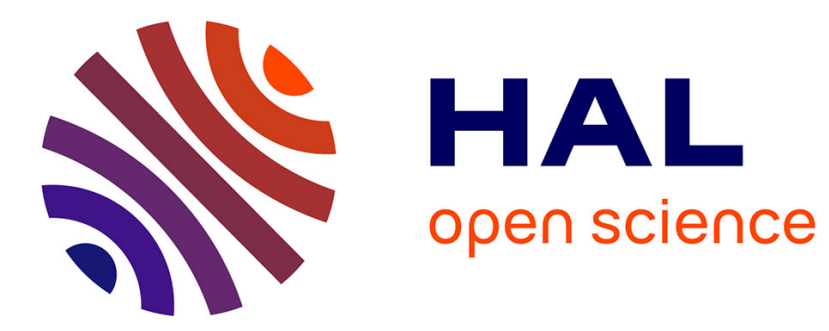

\title{
Using Gaussian Optics Measurement System to Characterize A New Wideband Low-Loss Antenna-Slot-Antenna
}

Hamza Kaouach, Amar Kabashi

\section{- To cite this version:}

Hamza Kaouach, Amar Kabashi. Using Gaussian Optics Measurement System to Characterize A New Wideband Low-Loss Antenna-Slot-Antenna. IEEE CAMA 2014, Nov 2014, Antibes Juan-lesPins, France. 10.1109/CAMA.2014.7003380 . hal-01150396v2

\section{HAL Id: hal-01150396 \\ https://hal.science/hal-01150396v2}

Submitted on 13 May 2015

HAL is a multi-disciplinary open access archive for the deposit and dissemination of scientific research documents, whether they are published or not. The documents may come from teaching and research institutions in France or abroad, or from public or private research centers.
L'archive ouverte pluridisciplinaire HAL, est destinée au dépôt et à la diffusion de documents scientifiques de niveau recherche, publiés ou non, émanant des établissements d'enseignement et de recherche français ou étrangers, des laboratoires publics ou privés. 


\section{Using Gaussian Optics Measurement System to Characterize A New Wideband Low-Loss Antenna-Slot-Antenna}

\author{
Hamza KAOUACH, Member, IEEE \\ ECE Department \\ CEL, Umm al-Qura University (UQU) \\ Makkah, KSA \\ hamza.kaouach@gmail.com
}

\author{
Amar KABASHI, Member, IEEE \\ ECE Department \\ CEL, Umm al-Qura University (UQU) \\ Makkah, KSA \\ amarkabashi@hotmail.com
}

\begin{abstract}
A new type of unit cell featuring wideband low loss characteristics is proposed for transmit-arrays (TA) and frequency selective surfaces (FSS) in Quasi-Optical applications. The TA is realized as a non-uniform array of antenna-resonatorantenna (ARA) elements and the FSS is realized as a uniform array of ARA elements. Each ARA element is a three layer structure consisting of two patch antennas and a slot resonator. The ARA elementary cell is designed and verified using finite element method simulation. A free space Gaussian optics measurement system (GOMS) is utilized to characterize the elementary cell. The measurement results show a $20.7 \%-3 \mathrm{~dB}$ $(12.2 \%-10 \mathrm{~dB})$ bandwidth and a maximum in-band insertion loss of $<0.2 \mathrm{~dB}$ for $42 \mathrm{GHz}$.
\end{abstract}

\section{INTRODUCTION}

Antenna-Resonator-Antenna (ARA) elements is composed of a receive antenna, a non-radiating resonant structure, and a transmit antenna operating between the input and output radiation ports [1]. These elements can be used for the Transmit-Array antennas (TA) [2], or to form FrequencySelective-Surface (FSS) [3].

In general, these elements are formed as three layer metallic structures: two resonant type planar antennas in the top and bottom layers, and one or more planar transmission line resonators in the middle layer. Microstrip antennas and coplanar waveguide (CPW) resonator have been mostly used for the antenna-resonator-antenna elements to form either TAs [2] by non-uniform array or FSS by uniform arrays. Using ARA elements in the transmit-arrays results in a band-pass transfer function, whose band-pass characteristics are desirable for radar, satellite [4], and power combining applications [5], where the distributed nature of the transmit-arrays can improve the power-handling and heat dissipation in the structure.

In terms of wave optics, a convex lens can be described as a device that transforms a diverging input spherical wave into a plane wave at the output, or an input plane wave into a converging spherical wave at the output [6]. In a transmitarray, the wave transformation is achieved by modifying the received phase distribution through the phase-delay of the ARA elements. In an array with optimal cell size, the inputoutput phase-delay in each cell is a function of the frequency, and can be written in terms of the S-parameters of the ARA cell as follows:

$$
\Phi_{m}(\omega)=-\angle S_{21}^{m}(\omega)
$$

An accurate measurement technique is vital to the assessment of the design method. In particular, the ability to accurately measure both transmission and reflection coefficients is critical in identifying the design errors and fabrication imperfections.

Usually, the transmit-array and frequency selective surface unit elements are measured either by shining a large sample with a plane wave in the anechoic chamber [4], or by replacing a small sample in a waveguide and measuring the S-parameters [7]. The first method obviously requires a large sample, and normally does not provide a way to measure the reflection. The waveguide technique can measure the reflection, but it has two disadvantages. First, the cross-sectional dimensions of a standard waveguide are not generally integer multiples of the FSS grid period. Second, as full metallic waveguide cannot carry a TEM mode, it cannot be used to measure the sample at normal or arbitrary angles of incidence. An alternative approach is to use a free space measurement setup that simulates the guided system. This method will be detailed in section III.

This paper highlights our approach to the AntennaResonator-Antenna element design, as a three-layer structure consisting of two patch antennas and a slot resonator, and further discusses effective measurement methods that can be used to characterize it. Especially, we introduce a method to extract the focusing S-parameters of the ARA based on the Gaussian optics measurement system. The focus will be on FSS applications.

\section{CONCLUSION}

High-efficiency wideband antenna-resonator-antenna elements has been designed using patch antennas and slot resonators. A uniform array of these elements features low-loss and wideband, which makes it an excellent candidate for frequency selective surfaces and filtering applications in quasi- 
optical amplifier arrays. Detuned versions of the proposed element can also be used to form other types of beam-formers. This ARA element has been adequately characterized in nonanechoic environments by using the Gaussian optics measurement system. The experimental results show good agreement with the simulation in terms of impedance matching and insertion loss. Two other cells are currently under investigation by the authors to design novel reconfigurable discrete lens antennas for high-speed wireless communication.

\section{REFERENCES}

[1] H. Kaouach, L. Dussopt, R. Sauleau, and Th. Koleck, "Deign and demonstration of an X-band transmit-array,” 3rd European Conference on Antennas and Propagation, Berlin, Germany, EuCAP, March 2009.

[2] H. Kaouach, L. Dussopt, J. Lanteri, R. Sauleau, and Th. Koleck, "Wideband Low-Loss Linear and Circular Polarization transmit-Arrays in V-Band," IEEE Trans. on Antennas and Propagation, Vol. 59, No. 7, pp. 25132523, July 2011.

[3] R.M.S. Cruz, A. G. Assuncao, and P. H. F. da Silva, "A new FSS design proposal for UWB applications," International workshop Antenna Technology (iWAT), Lisbon, Portugal, March 2010.

[4] H. Kaouach, L. Dussopt, R. Sauleau, and Th. Koleck, "Design and demonstration of 1-bit and 2-bits transmit-array at X-Band frequencies," $39^{\text {th }}$ European Microwave Conference, Rome, Italy, Sept. 2009.

[5] M. P. DeLisio, and R. A. York, "Quasi-Optical and Spatial Power Combining," IEEE Transactions on Microwave Theory and Techniques, Vol. 50, No. 3, March 2002.
[6] B. E. A. Saleh and M. C. Teich, "Fundamentals of Photonis," John Wiley and Sons, Hoboken, NJ, 1991.

[7] A. Clemente, L. Dussopt, R. Sauleau, P. Potier, and Ph. Pouliguen, “1Bit Reconfigurable Unit Cell Based on PIN Diodes for Transmit-Array Applications in X-Band,” IEEE Trans. on Antennas. and Propagation, Vol. 60, No. 5, pp. 2260-2269 May 2012.

[8] R. Garg, P. Bhartia, I. Bahl, and A. Ittipiboon, "Microstrip Antenna Design Handbook," Artech House, Boston, MA, 2001.

[9] G. L. Matthaei, L. Young, and E. M. T. Jones, "Microwave Filters: Impedance-Matching Networks, and Coupling Structures".

[10] R. S. Elliott, "Antenna Theory and Design, Revised Edition,” John Wiley and Sons, Hoboken, NJ, 2003.

[11] B. C. Deckman, “Active Quasi-Optics and Measurements,” Ph.D. thesis, California Institute of Technology, Pasadena, CA.

[12] M. A. Ali, S. C. Ortiz, T. Ivanov, and A. Mortazawi, "Analysis and measurement of hard-horn feeds for the excitation of quasi-optical amplifiers," IEEE Trans. Microwave Theory Tech., vol. 47, pp. 479487, April 1999.

[13] S. C. Ortiz, J. Hubert, L. Mirth, E. Schlecht, and A. Mortazawi, "A highpower Ka-band quasi-optical amplifier array,” IEEE Trans. Microwave Theory Tech., vol. 50, pp. 487-497, Feb. 2002.

[14] G. F. Engen and C. A. Hoer, "Thru-reflect-line: an improved technique for calibrating the dual six-port automatic network analyzer," IEEE Trans. Microwave Theory Tech., vol. 987-993, pp. 27, Dec. 1979.

[15] A. A.Tamijani, "Novel Components for Integrated Millimeter-Wave Front-Ends,” Ph. D. Thesis, in The University of Michigan 2004. 